\author{
Dawid Książek \\ Dagmara Lewicka** \\ Matgorzata Szeliga ${ }^{* * *}$
}

\title{
Zaangażowanie organizacyjne a profesjonalne na przykładzie pracowników szpitala
}

\section{Wstęp}

Współczesne organizacje stają przed zadaniem zredefiniowania sposobu postrzegania zarządzania dla uzyskiwania stałej przewagi konkurencyjnej. Dzieje się tak z powodu zmiany czynników zewnętrznego otoczenia organizacji, do których można zaliczyć proces globalizacji lub wzrost znaczenia gospodarki opartej na wiedzy (Zakrzewska-Bielawska 2009). W związku z tym, należy zwrócić uwagę na szczególną rolę zarządzania zasobami ludzkimi jako determinanty rozwoju organizacji. Pracownicy stają się bowiem podstawowym źródłem kreowania wartości oraz dźwignią zysków. Znaczenia nabiera zatem dbałość o rozwój kompetencji pracowników oraz kreowanie sprzyjających rozwojowi i uczeniu się warunków pracy jako działań integrujących kluczowych pracowników z organizacją (Lewicka 2012). Dla odnalezienia skutecznych metod zarządzania, które mogą stanowić o przewadze konkurencyjnej przedsiębiorstwa istotne jest więc odniesienie do potencjału tkwiącego w kapitale ludzkim jako strategicznym czynniku rozwoju firmy (Lewicka, Michniak 2013). W związku z powyższym, wartościową płaszczyzną dla prowadzenia badań wydają się być

\footnotetext{
* Mgr, Katedra Zarządzania Organizacjami, Kadrami i Prawa Gospodarczego, Akademia Górniczo-Hutnicza.

** Dr hab., profesor nadzwyczajny, Katedra Zarządzania Organizacjami, Kadrami i Prawa Gospodarczego, Akademia Górniczo-Hutnicza.

*** Mgr, Wydział Zarządzania, Informatyki i Nauk Społecznych, Wyższa Szkoła Biznesu w Dąbrowie Górniczej.

${ }^{1}$ Artykuł powstał w ramach grantu naukowego $\mathrm{nr}$ 18/18.200.263 (nr umowy UMO-2011/03/B/HS4/04 152), „Wpływ zaufania organizacyjnego na zaangażowanie pracowników" finansowanego przez Narodowe Centrum Nauki.
} 
zagadnienia odnoszące się do społecznych czynników organizacji, do których wlicza się problematykę zaangażowania pracowników, a w tym zaangażowanie organizacyjne oraz zaangażowanie $\mathrm{w}$ wykonywaną profesję.

\section{Zaangażowanie organizacyjne a zaangażowanie $w$ wykonywaną profesję}

Zaangażowanie pracowników jest jednym z mierników zarządzania zasobami ludzkimi, który nabiera coraz większego znaczenia w zarządzaniu przedsiębiorstwem. Dzieje się tak, ponieważ wpływa to na szereg obszarów funkcjonowania organizacji. W literaturze przedmiotu wykazano pozytywną korelację zaangażowania z wydajnością pracy (Rich i in. 2010), zachowaniami obywatelskimi (Schaufeli i in. 2006), wynikami ekonomicznymi (Xanthopoulou i in. 2009), zaufaniem organizacyjnym i jakością środowiska pracy (Lewicka, Michniak 2012), efektywnością organizacji (Meyer, Hersovitch 2001) oraz satysfakcją z wykonywanej pracy i fluktuacją (Jahnson, Groff, Taing 2009). Z kolei niskie zaangażowanie pracowników zwiększa prawdopodobieństwo występowania zachowań nieetycznych, takich jak kradzieże, sabotaż i agresja (Luchak, Gellatly 2007).

Badacze zwracają także uwagę na fakt, iż pracownik zaangażowany stanowi nową jakość w porównaniu z pracownikiem zadowolonym (Lewicka 2013). Zaangażowanie przejawia się bowiem $\mathrm{w}$ gotowości do podejmowania samodzielnych decyzji oraz identyfikacją z przedsiębiorstwem przejawiającą się w odpowiedzialności za jej działania, łącznie z częściowym podporządkowaniem własnych interesów interesom organizacji (Juchnowicz 2010).

Zaangażowanie występuje w różnych formach. W literaturze wyróżnia się między innymi zaangażowanie organizacyjne (organisational commitment) (Meyer, Herscovitch 2001), zaangażowanie w pracę (employee engagement) (Hundley i in. 2005), zaangażowanie w wykonywaną profesję (Gallagher, McLean Parks 2001).

Zaangażowanie organizacyjne (organizational commitment) posiada wysoką wartość dla zarządzania zasobami ludzkimi, ze względu na przekonanie, iż organizacje zatrudniające zaangażowanych pracowników osiągają wyższy stopień efektywności, ponieważ zaangażowani pracownicy bardziej utożsamiają się z celami organizacji niż ich mniej zaangażowani koledzy oraz charakteryzują się większym przywiązaniem do organizacji (Lewicka 2013).

Według definicji zaangażowania organizacyjnego, którą prezentują J. P. Meyer i L. Herscovitch, zaangażowanie to konstrukt, na który składają się trzy aspekty: afektywny, normatywny oraz trwania (Meyer, Herscovitch 2001). Zaangażowanie afektywne oznacza emocjonalne przywiązanie do organizacji i identyfikowanie się $\mathrm{z}$ nią, normatywne - poczucie moralnego obowiązku 
do pozostania $\mathrm{w}$ organizacji, $\mathrm{z}$ kolei trwania przejawia się $\mathrm{w}$ niechęci pracownika do ponoszenia kosztów związanych z ewentualną zmianą miejsca pracy (Meyer, Herscovitch 2001). Należy zwrócić uwagę na fakt, iż właściwe jest rozpatrywanie powyższych aspektów zaangażowania jako komponentów niż rodzajów, bowiem związek pracownika z organizacją może odzwierciedlać w różnym stopniu wszystkie trzy składniki (Allen, Mayer 1991). Najcenniejsze dla organizacji jest zaangażowanie afektywne. Osoby $\mathrm{z}$ wysokim zaangażowaniem afektywnym pozostają w organizacji z wyboru (Allen, Meyer 1990; Meyer i in. 2002). Innymi słowy można zaryzykować twierdzenie, że pracownik, który posiada wysoki poziom zaangażowania afektywnego po prostu czerpie przyjemność z przynależności do organizacji. Jest to bardzo pożądany stan. Związek pomiędzy zaangażowaniem afektywnym a wysoką efektywnością pracy jest wskazywany w wielu badaniach. (Angle, Perry 1981; Becker i in. 1996). Badania wskazują także negatywny związek pomiędzy zaangażowaniem afektywnym i intencją odejścia (zmiany pracy) oraz faktyczną zmianą pracy (Meyer i in. 2002; Vanderberghe, Bentein 2009). Wyniki te potwierdzone zostały także w badaniach przeprowadzonych w sektorze IT, wskazując pozytywny i istotny związek pomiędzy zaangażowaniem afektywnym, a redukcją intencji odejścia i wzrostem satysfakcji z pracy (Magni, Pennarola 2008).

Zaangażowanie w profesję definiuje się jako silną identyfikację jednostki z wykonywanym zawodem (Otley, Pierce 1996). Charakteryzuje się nastawieniem pracownika na realizację własnych interesów w ramach wykonywanej pracy (Jahnson, Groff, Taing 2009). Jest to rodzaj zaangażowania, które wpisuje się najsilniej w definicje zaangażowania jako indywidulanego przejawiania wyznawanych wartości na danym stanowisku w pracy (Werkmeister 1967). Na różnicę w koncepcji zaangażowania organizacyjnego i zaangażowania w wykonywaną profesję zwrócili między innymi uwagę Mabey i Hooker (1994), którzy odnotowali inne przyczyny wycofania się pracowników z organizacji przejawiających te dwa rodzaje zaangażowania. Należy podkreślić, że w interesie każdej organizacji chcącej uzyskać stałą przewagę konkurencyjną, jest utrzymanie równowagi pomiędzy zaangażowaniem organizacyjnym i zaangażowaniem w wykonywaną profesję (Borkowska 2010).

\section{Cel badań i metoda badawcza}

Głównym celem badania było ustalenie, czy i w jaki sposób zaangażowanie organizacyjne wpływa na zaangażowanie $\mathrm{w}$ wykonywaną profesję. $\mathrm{W}$ tym celu, dla każdego z rodzajów zaangażowania wyodrębniono trzy komponenty: afektywny, trwania oraz normatywny. W związku z tym, interesującym problemem badawczym było także określenie poziomu występowania poszczególnych kom- 
ponentów zaangażowania organizacyjnego i zaangażowania w wykonywaną profesję oraz sprawdzenie, które z wymienionych komponentów wpływają na siebie najsilniej.

$\mathrm{W}$ badaniach podjętych na potrzeby niniejszej pracy zastosowano metodę sondażu diagnostycznego. Narzędziem badawczym był kwestionariusz ankiety. W celu określenia pomiaru postawy ankietowanego w odniesieniu do twierdzeń zawartych w kwestionariuszu zastosowano skalę Likerta. Zmierzenie zaangażowania organizacyjnego dla komponentu afektywnego, trwania i normatywnego dokonano przy użyciu 8 twierdzeń dla każdego z czynników. Z kolei dla zmierzenia zaangażowania w wykonywaną profesję zastosowano 3 twierdzenia dla komponentu afektywnego, 2 dla komponentu trwania oraz 3 dla komponentu normatywnego. Przykłady twierdzeń wraz z ich przyporządkowaniem do badanych czynników prezentuje tabela 1 .

Tabela 1. Przykłady twierdzeń mierzących badane czynniki

\begin{tabular}{|c|c|c|l|}
\hline $\begin{array}{c}\text { Rodzaj } \\
\text { zaangażowania }\end{array}$ & Komponent & $\begin{array}{c}\text { Nr twierdzenia w } \\
\text { kwestionariuszu }\end{array}$ & \multicolumn{1}{|c|}{ Treść twierdzenia } \\
\hline \multirow{2}{*}{$\begin{array}{c}\text { Zaangażowanie } \\
\text { organizacyjne }\end{array}$} & Afektywny & 47 & $\begin{array}{l}\text { Będę szczęśliwy/a mogąc pracować } \\
\text { w mojej firmie do końca aktywno- } \\
\text { ści zawodowej }\end{array}$ \\
\cline { 2 - 4 } & Trwania & 55 & $\begin{array}{l}\text { Zmiana pracy może się dla mnie } \\
\text { okazać zbyt kosztowna }\end{array}$ \\
\cline { 2 - 4 } & Normatywny & 65 & $\begin{array}{l}\text { Zbyt częsta zmiana pracy wydaje } \\
\text { mi się nieetyczna }\end{array}$ \\
\hline \multirow{2}{*}{$\begin{array}{c}\text { Zaangażowanie } \\
\text { w wykonywaną } \\
\text { profesję }\end{array}$} & Trektywny & 122 & $\begin{array}{l}\text { Bardziej utożsamiam się z moją } \\
\text { profesją niż z firmą, w której pracu- } \\
\text { je }\end{array}$ \\
\cline { 2 - 4 } & Normatywny & 127 & $\begin{array}{l}\text { Zmiana profesji wymagałaby ode } \\
\text { mnie zbyt wielkiego poświęcenia }\end{array}$ \\
\cline { 2 - 4 } & 129 & $\begin{array}{l}\text { Czułbym/łabym się winny/a gdy- } \\
\text { bym zmienił/a profesję }\end{array}$ \\
\hline
\end{tabular}

Źródło: opracowanie własne.

Badanie ankietowe przeprowadzono w szpitalu wojewódzkim, w którym w dniu badania zatrudnionych było 1292 pracowników. Na grupę respondentów składało się $20 \%$ zatrudnionych w jednostce, tj. 258 pracowników. Należy zwrócić uwagę na fakt, że podmiot leczniczy jest przykładem organizacji wpisującej się w sferę publiczną funkcjonowania społeczeństwa. Za przykład badań z zakresu zarządzania zasobami ludzkimi odnoszących się do organizacji budżetowych można przytoczyć badania D. Lewickiej i P. Oleśniewicza (2011) dotyczące sa- 
tysfakcji nauczycieli lub B. Metcaffe i G. Dick'a (2001) traktujących o zaangażowaniu pracowników policji. W związku $\mathrm{z}$ tym poniższa publikacja stanowi próbę uzupełnienia badań organizacji budżetowych $\mathrm{z}$ zakresu zaangażowania organizacyjnego oraz zaangażowania w wykonywaną profesję.

Odsetek kobiet w badanej próbie był znaczący: około 73\%. Średnia wieku ankietowanych to 45,7 lat, przy odchyleniu standardowym 8,8 roku. Najmłodsza osoba była w wieku 23 lat, najstarsza natomiast - 62 lat. Wykształcenie wyższe miało około $42 \%$ ankietowanych, a wykształcenie policealne - ponad $17 \%$ respondentów. Dużą grupę stanowiły osoby z wykształceniem średnim $(32,2 \%)$. Analizowaną próbę uzupełniali badani $\mathrm{z}$ wykształceniem zawodowym $(8,1 \%)$ i podstawowym $(0,4 \%)$.

Zdecydowana większość pracowników miała podpisaną umowę na czas nieokreślony $(82,9 \%)$, a niewielki odsetek - umowę na czas określony $(12,8 \%)$. Inne rodzaje umów podpisanych przez szpital $\mathrm{z}$ respondentami to: umowa na zastępstwo $(2,7 \%)$, umowa zlecenie $(1,2 \%)$, umowa na czas wykonania określonej pracy $(0,4 \%)$. W analizowanej próbie najliczniejszą grupę tworzyły pielęgniarki i położne (45,3\%). Badaniu ankietowemu poddano również pracowników gospodarczych, obsługi i zaplecza technicznego $(18,6 \%)$, techników, statystyków, rejestratorki i pozostały średni personel medyczny $(13,6 \%)$, lekarzy $(12,4 \%)$, administrację $(6,2 \%)$ i pozostały wyższy personel medyczny $(3,9 \%)$.

Zastosowaną metodą badań była jednoczynnikowa analiza wariancji (ANOVA) oraz testowanie post hoc za pomocą testu Bonferroniego. Korelacje pomiędzy zmiennymi rangowymi i ilościowymi sprawdzono za pomocą współczynnika korelacji rang Spearmana. W analizach statystycznych przyjęto poziom istotności $\mathrm{p}=0,05$.

\section{Zaangażowanie organizacyjne pracowników podmiotu leczniczego}

Badając zaangażowanie organizacyjne, najwyższy średni wynik uzyskano dla normatywnego komponentu zaangażowania - 31,5 pkt $(\mathrm{SD}=5,44)$, natomiast najniższy średni wynik stwierdzono dla komponentu afektywnego $-25,3$ pkt $(\mathrm{SD}=5,91)$. Średnia dla komponentu trwania wyniosła $28,8 \mathrm{pkt}(\mathrm{SD}=6,02)$. W przypadku komponentu trwania stwierdzono statystycznie istotną różnicę między grupami zawodowymi $(\mathrm{F}=2,8 ; \mathrm{p}=0,018)$. Analiza post hoc wykazała, że pod względem średnich wyników grupa lekarzy istotnie różniła się od średniego personelu medycznego. Lekarze uzyskali najniższy wynik dla komponentu trwania, natomiast średni personel odnotował najwyższe średnie wyniki (tabela 2). 
Tabela 2. Miary tendencji centralnej oraz rozproszenia

- zaangażowanie organizacyjne z podziałem na grupy

\begin{tabular}{lcc|cc|cc}
\hline \hline & \multicolumn{2}{c|}{$\begin{array}{c}\text { Afektywny } \\
\text { komponent }\end{array}$} & \multicolumn{2}{c|}{$\begin{array}{c}\text { Komponent } \\
\text { trwania }\end{array}$} & \multicolumn{2}{c}{$\begin{array}{c}\text { Normatywny } \\
\text { komponent }\end{array}$} \\
\cline { 2 - 7 } & M & SD & M & SD & M & SD \\
\hline Lekarze & 24,6 & 5,42 & 25,6 & 5,80 & 30,1 & 4,61 \\
Pielęgniarki i położne & 25,6 & 5,68 & 28,6 & 6,16 & 31,9 & 5,42 \\
Pozostały średni personel medyczny & 26,2 & 5,24 & 30,2 & 4,59 & 31,4 & 4,80 \\
Pracownicy gospodarczy oraz zaplecza technicz- & 24,8 & 6,91 & 29,2 & 6,47 & 31,3 & 6,19 \\
nego & & & & & & \\
Administracja & 26,1 & 6,63 & 30,7 & 5,95 & 33,1 & 5,59 \\
Inny wyższy personel medyczny & 23,0 & 6,27 & 30,3 & 4,35 & 28,7 & 5,54 \\
\hline ANOVA & $\mathrm{F}=0,73 ;$ & $\mathrm{F}=2,80 ;$ & $\mathrm{F}=1,39 ;$ \\
& $\mathrm{p}=0,598$ & $\mathrm{p}=0,018$ & $\mathrm{p}=0,228$ \\
\hline \hline
\end{tabular}

Źródło: opracowanie własne.

Korelacja między badanymi zmiennymi rysuje się następująco:

- im wyższy wynik dla komponentu trwania $(\mathrm{p}<0,001)$ i normatywnego ( $\mathrm{p}<0,001)$, tym wyższy wynik dla komponentu afektywnego. Wraz ze wzrostem stażu pracy w szpitalu następuje wzrost afektywnego komponentu $(\mathrm{p}=0,050)$

- im wyższy wynik dla afektywnego $(\mathrm{p}<0,001)$ i normatywnego $(\mathrm{p}<0,001)$ komponentu, tym wyższy wynik dla komponentu trwania. Wraz $\mathrm{z}$ wiekiem ankietowanego $(\mathrm{p}=0,014)$, wzrostem stażu pracy ogółem $(\mathrm{p}=0,005)$ i stażu pracy $\mathrm{w}$ szpitalu $(\mathrm{p}=0,014)$ oraz spadkiem poziomu wykształcenia $(\mathrm{p}<0,001)$ następuje wzrost komponentu trwania;

- wraz z wiekiem ankietowanego $(\mathrm{p}=0,003)$, wzrostem stażu pracy ogółem $(\mathrm{p}=0,004)$ i stażu pracy w szpitalu $(\mathrm{p}=0,001)$ oraz spadkiem poziomu wykształcenia $(\mathrm{p}=0,002)$ następuje wzrost normatywnego komponentu.

\section{Zaangażowanie w wykonywaną profesję pracowników podmiotu leczniczego}

Badając zaangażowanie w profesję stwierdzono, że średnia dla afektywnego komponentu wyniosła $12,7 \mathrm{pkt}(\mathrm{SD}=2,28)$. Średnia dla komponentu trwania to 8,2 pkt $(\mathrm{SD}=1,69)$, a dla komponentu normatywnego $-11 \mathrm{pkt}(\mathrm{SD}=2,4)$. 
Stwierdzono statystycznie istotną różnicę między grupami zawodowymi dla afektywnego komponentu $(\mathrm{F}=11,2 ; \mathrm{p}<0,001)$. Analiza post hoc wykazała, że pod względem średnich wyników grupa pracowników gospodarczych istotnie różniła się od lekarzy ( $\mathrm{p}<0,001)$, pielęgniarek i położnych $(\mathrm{p}<0,001)$, średniego personelu medycznego $(\mathrm{p}<0,001)$ i wyższego personelu medycznego $(\mathrm{p}=0,002)$. Lekarze uzyskali najwyższy wynik dla afektywnego komponentu, najniższy uzyskali natomiast pracownicy gospodarczy.

Stwierdzono statystycznie istotną różnicę między grupami zawodowymi dla komponentu trwania $(\mathrm{F}=7,2 ; \mathrm{p}<0,001)$. Analiza post hoc wykazała, że pod względem średnich wyników grupa pracowników gospodarczych istotnie różniła się od lekarzy ( $\mathrm{p}<0,001)$, pielęgniarek i położnych $(\mathrm{p}<0,001)$ oraz wyższego personelu medycznego $(\mathrm{p}=0,013)$. Lekarze i pozostały wyższy personel medyczny uzyskali najwyższy wynik dla tego komponentu, najniższy uzyskali natomiast pracownicy gospodarczy (tabela 3).

Tabela 3. Miary tendencji centralnej oraz rozproszenia

- zaangażowanie w profesję z podziałem na grupy

\begin{tabular}{|c|c|c|c|c|c|c|}
\hline & \multicolumn{2}{|c|}{$\begin{array}{l}\text { Afektywny } \\
\text { komponent }\end{array}$} & \multicolumn{2}{|c|}{$\begin{array}{c}\text { Komponent } \\
\text { trwania }\end{array}$} & \multicolumn{2}{|c|}{$\begin{array}{c}\text { Normatywny } \\
\text { komponent }\end{array}$} \\
\hline & $\mathbf{M}$ & SD & $\mathbf{M}$ & SD & $\mathbf{M}$ & SD \\
\hline Lekarze & 13,9 & 1,23 & 9,1 & 1,13 & 11,5 & 1,92 \\
\hline Pielęgniarki i położne & 13,0 & 1,85 & 8,4 & 1,59 & 11,2 & 2,40 \\
\hline Pozostały średni personel medyczny & 13,1 & 2,05 & 8,1 & 1,71 & 10,7 & 3,01 \\
\hline $\begin{array}{l}\text { Pracownicy gospodarczy oraz zaplecza technicz- } \\
\text { nego }\end{array}$ & 10,8 & 3,04 & 7,2 & 1,84 & 10,5 & 2,11 \\
\hline Administracja & 12,6 & 1,75 & 7,7 & 1,35 & 10,8 & 2,74 \\
\hline Inny wyższy personel medyczny & 13,6 & 1,58 & 9,1 & 1,60 & 10,8 & 1,93 \\
\hline ANOVA & \multicolumn{2}{|c|}{$\begin{array}{l}F=11,2 \\
p<0,001\end{array}$} & \multicolumn{2}{|c|}{$\begin{array}{l}F=7,16 \\
p<0,001\end{array}$} & \multicolumn{2}{|c|}{$\begin{array}{l}F=1,10 \\
p=0,361\end{array}$} \\
\hline
\end{tabular}

Źródło: opracowanie własne.

Korelacja między badanymi zmiennymi występowała w sposób następujący:

- im wyższy wynik dla komponentu trwania $(\mathrm{p}<0,001)$ i normatywnego ( $\mathrm{p}<0,001$ ), tym wyższy wynik dla komponentu afektywnego. Wraz ze wzrostem stażu pracy w szpitalu $(\mathrm{p}=0,032)$ i wzrostem poziomu wykształcenia $(p=0,015)$ następował wzrost afektywnego komponentu; 
- im wyższy wynik dla afektywnego $(\mathrm{p}<0,001)$ i normatywnego ( $\mathrm{p}<0,001)$ komponentu, tym wyższy wynik dla komponentu trwania. Wraz ze wzrostem poziomu wykształcenia $(\mathrm{p}=0,004)$ następował wzrost komponentu trwania;

- im wyższy wynik dla afektywnego $(\mathrm{p}<0,001)$ i trwania $(\mathrm{p}<0,001)$ komponentu, tym wyższy wynik dla komponentu normatywnego. Wraz $\mathrm{z}$ dłuższym stażem pracy w szpitalu $(\mathrm{p}=0,044)$ następował wzrost normatywnego komponentu.

\section{Relacja pomiędzy zaangażowaniem organizacyjnym a zaangażowa- niem w wykonywaną profesję pracowników podmiotu leczniczego}

Wszystkie komponenty zaangażowania organizacyjnego dodatnio korelują z komponentami zaangażowania w profesję. Wartości współczynników korelacji wraz z poziomami istotności zestawiono $\mathrm{w}$ tabeli 4.

Tabela 4. Wartości współczynników korelacji

\begin{tabular}{clccc}
\hline \hline & & $\begin{array}{c}\text { Afektywny } \\
\text { komponent } \\
\text { (w profesję) }\end{array}$ & $\begin{array}{c}\text { Komponent } \\
\text { trwania } \\
\text { (w profesję) }\end{array}$ & $\begin{array}{c}\text { Normatywny } \\
\text { komponent } \\
\text { (w profesję) }\end{array}$ \\
\hline $\begin{array}{c}\text { Afektywny komponent } \\
\text { (organizacyjne) }\end{array}$ & Współczynnik korelacji & 0,426 & 0,367 & 0,394 \\
\hline $\begin{array}{c}\text { Istotność (dwustronna) } \\
\text { (organazacyjne) }\end{array}$ & 0,000 & 0,000 & 0,000 \\
\hline $\begin{array}{c}\text { Normatywny } \\
\text { komponent } \\
\text { (organizacyjne) }\end{array}$ & Współczynnik korelacji & 0,402 & 0,394 & 0,389 \\
\hline \hline
\end{tabular}

Źródło: opracowanie własne.

Z przedstawionych wyników badań można wywnioskować, że wraz ze wzrostem każdego z komponentów zaangażowania organizacyjnego następuję wzrost zaangażowania w wykonywaną profesję. Najsilniejszy związek występuje pomiędzy komponentami normatywnymi badanych konstruktów, natomiast najsłabszy między komponentem normatywnym zaangażowania organizacyjnego a komponentem trwania zaangażowania w profesję. Oznacza to, iż czynnik moralnego poczucia obowiązku pozostania w organizacji ma najsilniejszy wpływ 
na czynnik moralnego obowiązku wykonywania pracy w sposób profesjonalny. Warto zwrócić uwagę na specyfikę organizacji jaką jest podmiot leczniczy, dla którego wartością jest lub powinno być - zdrowie pacjenta. Pod tym kątem można zadać pytanie: czy pracownicy organizacji nie posiadającej takiej specyfiki również byliby w podobnym stopniu zaangażowani na płaszczyźnie normatywnej.

\section{Podsumowanie}

Zaangażowanie jest podstawowym czynnikiem determinującym sukces organizacji - stąd konieczność dostrzegania tego aspektu w procesie zarządzania. Zaangażowanie personelu, zarówno wysokiego, jak i najniższego szczebla, wpływa na efektywność pracowników, a tym samym przekłada się na zdolność organizacji do osiągania przewagi konkurencyjnej.

Przeprowadzone badanie miało na celu analizę doświadczeń pracowników podmiotu leczniczego dotyczących zaangażowania. Wyniki ukazują pozytywną korelację pomiędzy zaangażowaniem organizacyjnym a zaangażowaniem w wykonywana profesję. Ponadto badanie jednoznacznie wskazuje, iż zaangażowanie w analizowanej placówce medycznej ma charakter wysoce zróżnicowany. Inne jego komponenty charakteryzują pracowników zatrudnionych na niższych szczeblach, inne - pracowników wysokiego szczebla. Spostrzeżenie to powinno zwrócić uwagę kadry zarządzającej na konieczność dokładniejszej analizy sytuacji.

Jako kierunki przyszłych rozważań z zakresu problematyki zaangażowania pracowników warto wskazać na zbadanie innych rodzajów zaangażowania oraz poszerzenie badań na organizację spoza sfery budżetowej. Ponadto, interesujące byłoby zastosowanie metod jakościowych dla poszerzenia analizy badanych zjawisk.

\section{BIBLIOGRAFIA}

Allen N. J., Meyer J. P. (1990), The Measurement and Antecedent of Affective, Continuance and Normative Commitment to the Organization, ,Journal of Occupational Psychology”, vol. 63, p. 1-18.

Angle H. L., Perry J. L. (1981), An Empirical Assessment of Organizational Commitment and Organizational Effectiveness, „Administrative Science Quarterly”, vol. 26, no. 1, p. 1-14.

Becker B., Berhart B. (1996), The Impact of Human Resource Management on Organizational Performance: Progress and Prospects, „Academy of Management Journal”, vol. 39, no. 4, p. 779-801.

Borkowska S. (red.), (2010), Rola ZZL w kreowaniu innowacyjności organizacji, C. H. Beck, Warszawa. 
Eisenberger R., Armeli S., Rexwinkel B., Lynch P. D., Rhoades L. (2001), Reciproaction of Perceived Organizational Support, ,Journal of Applied Psychology”, vol. 86, p. 42-51.

Gallagher D. G., McLean Parks J. (2001), I pledge thee my troth... contingently: commitment and the contingent work relationship, „Human Resources Management Review”, vol. 3, p. 181-208.

Jahnson R. E., Groff K. W., Taing M. U. (2009), Nature of the interactions among organizational commitments: complementary, competitive or synergistic?, „British Journal of Management”.

Juchnowicz M. (2010), Zarzadzanie przez zaangażowanie. Koncepcja, kontrowersje, aplikacje, PWE, Warszawa.

Kahn W. A. (1990), Psychological conditions of personal engagement and disengagement at work, „Academy of Management Journal”, vol. 33.

Lewicka D. (red.), (2013), Zapobieganie patologiom organizacji, PWN, Warszawa.

Lewicka D., Michniak J. (2013), Relacje między zaufaniem, zaangażowaniem oraz jakościa środowiska pracy w firmach sektora MPŚ, [w:] Zarzadzanie zasobami ludzkimi w matych i średnich przedsiębiorstwach, Wydawnictwo Wolters Kluwer SA, Warszawa.

Lewicka D., Oleśniewicz P. (2011), Czynniki ksztattujące satysfakcję nauczycieli z wykonywanej pracy, Rozprawy Naukowe Akademii Wychowania Fizycznego we Wrocławiu, nr 35, s. 50-56.

Luchak A. A., Gellattly I. R. (2007), A Comparison of Linear and Nonlinear Relations between Organizational Commitment and Work Outcomes, „The Journal of Applied Psychology”, vol. 92, no. 3, s. 786-793.

Mabey C., Hooker C. (1994), What does it mean to be a committed employee?, [w:] Vinten G. (eds.), Whistleblowing - Subversion or Corporate Citizenship?, St Martin's Press, New York, NY.

Metcaffe B., Dick G. (2001), Policing: An International Journal of Police Strategies and Management, vol. 24, no. 3, p. 399-420.

Meyer J. P., Stanley D. J., Herscovitch L., Topolnytsky L. (2002), Affective, continuance, and normative commitment to the organization: a meta-analysis of antecedents, correlates, and consequences, ,Journal of Vocational Behavior”, vol. 61, p. 20-52.

Meyer J. P., Hersovitch L. (2001), Commitment in the Workplace: Towards a general model, „Human Resource Management Review", no. 11, p. 299-326.

Otley D. T., Pierce, B. J. (1996), The operation of control systems in large audit firms, Auditing: „A Journal of Practice and Theory”, vol. 15, no. 2, p. 65-84.

Pennarola F., Magni M. (2008), Intra-organizational relationships and technology acceptance, „International Journal of Information Management”, vol. 29, no. 6, p. 517-523.

Rich B. L., Lepine J. A., Crawford E. R. (2010), Job Engagement: Antecedents and effects on job performance, ,Academy of Management Journal”, no. 53, p. 617-635.

Roberts D. R., Davenport T. O. (2002), Job engagement: Why it's important and how to improve it, „Employment Relation Today”, Willey Periodicals.

Schaufeli W. B., Taris T. W., Bakker A. B. (2006), Dr Jekyll and Mr Hyde: On the Differences between Work Engagement and Workaholism, [w:] Burke R. J. (red.), Research Companion to Working Time and Work Addiction, Northampton: Edward Elgar.

Werkmeister W. (1967), Man and his Values, University of Nebraska Press, Lincol, IL.

Xanthopoulou D., Bakker A. B., Demerouti E., Schaufeli W. B. (2009), Work Engagement and Financial Returns: A diary study on the role of job and personal resources, ,Journal of Occupational and Organizational Psychology", no. 82, p. 183-200.

Vandenberghe C., Bentein K. (2009), A closer look at the relationship between affective commitment to supervisors and organizations and turnover, ,Journal of Occupational and Organizational Psychology”, vol. 82, p. 331-348. 
Zakrzewska-Bielawska A. (2009), Umiędzynarodowienie i globalizacja a strategie rozwoju przedsiębiorstw, [w:] Potocki A. (red.), Instrumenty i obszary przeobrażeń i zmian organizacyjnych w warunkach globalizacji, Difin, Warszawa.

\section{Organizational commitment as a factor creating a commitment to the profession of employees based on medical unit example}

\section{SUMMARY}

Nowadays commitment become a new quality in the human resources management. This is because employee characterized by commitment identify more with organization. Thus, for the management of modern organization commitment is the one of the most important source of competitive advantage. This paper presents reflections on the relationship between organizational commitment and commitment to the profession. Measurement and analysis is based on rank Spearman Correlation, Univariate analysis of variance (ANOVA) and Bonferroni Test, which was created using a survey among 258 respondents. 